\title{
Shallow subsurface geology and Vs characteristics of sedimentary units throughout Rasht City, Iran
}

\author{
Latif Samadi and Behzad Mehrabi \\ Department of Geology, Tarbiat Moalem University, Tehran, Iran
}

\begin{abstract}
The Manjil-Rudbar earthquake of June 1990 caused widespread damage to buildings in the city of Rasht located $60 \mathrm{~km}$ from the epicenter. Seismic surveys, including refraction P-wave, S-wave and downhole tests, were carried out to study subsurface geology and classify materials in the city of Rasht. Rasht is built on Quaternary sediments consisting of old marine (Q1m), deltaic (Q2d), undivided deltaic sediments with gravel (Qdg) and young marine $(\mathrm{Q} 2 \mathrm{~m})$ deposits. We used the variations of $\mathrm{Vp}$ in different materials to separate sedimentary boundaries. The National Earthquake Hazard Reduction Program (NEHRP) scheme was used for site classification. Average S-wave velocity to a depth of $30 \mathrm{~m}$ was used to develop site categories, based on measured Vs values in 35 refraction seismic profiles and 4 downhole tests. For each geological unit histograms of S-wave velocity were calculated. This study reveals that the $\bar{V} s(30$ of most of the city falls into categories D and C of NEHRP site classification. Average horizontal spectral amplification (AHSA) in Rasht was calculated using $\bar{V} s(30$. The AHSA map clearly indicates that the amplification factor east and north of the city are higher than those of south and central parts. The results show that the lateral changes and heterogeneities in Q1m sediments are significant and most damaged buildings in 1990 Manjil earthquake were located in this unit.
\end{abstract}

Key words Shear wave velocity $-\bar{V} s(30-N E H R P$ site classification - Rasht - Iran

\section{Introduction}

It is well known that local site conditions could give rise to significant local amplification of ground motion during earthquakes. Historic earthquakes have shown that damage to structures is often significantly greater on soft sediments than on stiff sediments. Wood (1908) and Reid (1910) have shown that the intensity of ground motions during the 1906 San Francisco

Mailing address: Dr. Latif Samadi, Department of Geology, Tarbiat Moalem University, 49 Mofateh Avenue, Tehran, 15614-Iran; e-mail: samadi@tmu.ac.ir earthquake were strongly related to the local site conditions. Investigations of ground-motion properties indicate that the amplitude, frequency content, and shape of seismic waves are modified by the soils and sediments through which they are transmitted (Joyner and Boore, 1988; Borcherdt, 1994; Zeng, 1993; Olsen and Archuleta, 1996). Shear wave velocity is an important parameter for evaluating the dynamic behavior of soil in the shallow subsurface. Thus, site characterization in calculating seismic hazard is usually based on the near surface shear wave velocity values. Seismic wave velocity in soil depends on the nature of soils and sediments and factors such as cementation, fabric, age, heterogeneity, wet or dry conditions (Gorynov, 1992). The Vs in rocks mainly depends on the type, mineralogy, texture, degree of weathering and alteration. The average shear wave velocity in the upper $30 \mathrm{~m}$ was globally adopted after the National Earthquake Hazard 
Reduction Program (NEHRP) classification in the USA.

Midorikawa (1987), Borcherdt et al. (1991), Borcherdt (1992; 1994), Seed et al. (1992), Dobry et al. (1992), Boore et al. (1997) have shown supportive evidence for empirical relationships between site amplification factor and Vs(30). Wills et al. (2000) developed a siteconditions map for California based on $\mathrm{Vs}(30)$ measured in 556 seismic profiles and geological similarities between units. Shafiee and Azadi (2007) completed the classification of geological units throughout Tehran. NEHRP uses Vs(30) to rank sites into five broad classes (Building Seismic Safety Council - BSSC, 2001), as shown in table I. Consideration of site conditions is a vital step in analyzing and predicting earthquake ground motion particularly for major cities situated in earthquake-prone areas. Rasht, the capital of Gilan province is located in a tectonically active region, between the Caspian Sea and the Alborz Mountain (fig. 1). According to the Iranian National Building
Code (Standard No. 2800, Building and Housing Research Center - BHRC, 1999), it is classified as a region of very high earthquake hazard. In 1990, Manjil earthquake caused widespread destruction in the urban area of Rasht. The cities of Rudbar, Manjil, and Lushan, and 700 villages were destroyed. At least three hundred more villages were slightly damaged. One hundred thousand adobe houses sustained major damage or collapsed resulting in more than twenty five thousand fatalities, and sixty thousand injuries. About five hundred thousand people were left homeless. In 1992, refraction seismic tests and some geoelectical sounding were conducted in the marginal territory of Rasht. However, due to the lack of suitable data base, a through site classification of Rasht was not accomplished. In 2006, as part of national geotechnical and seismological survey program, investigation for strengthening the water supply system of Rasht was conducted which lasted for a year. In this project, 12 boreholes, $26 \mathrm{P}$ and $26 \mathrm{~S}$ refraction seismic tests

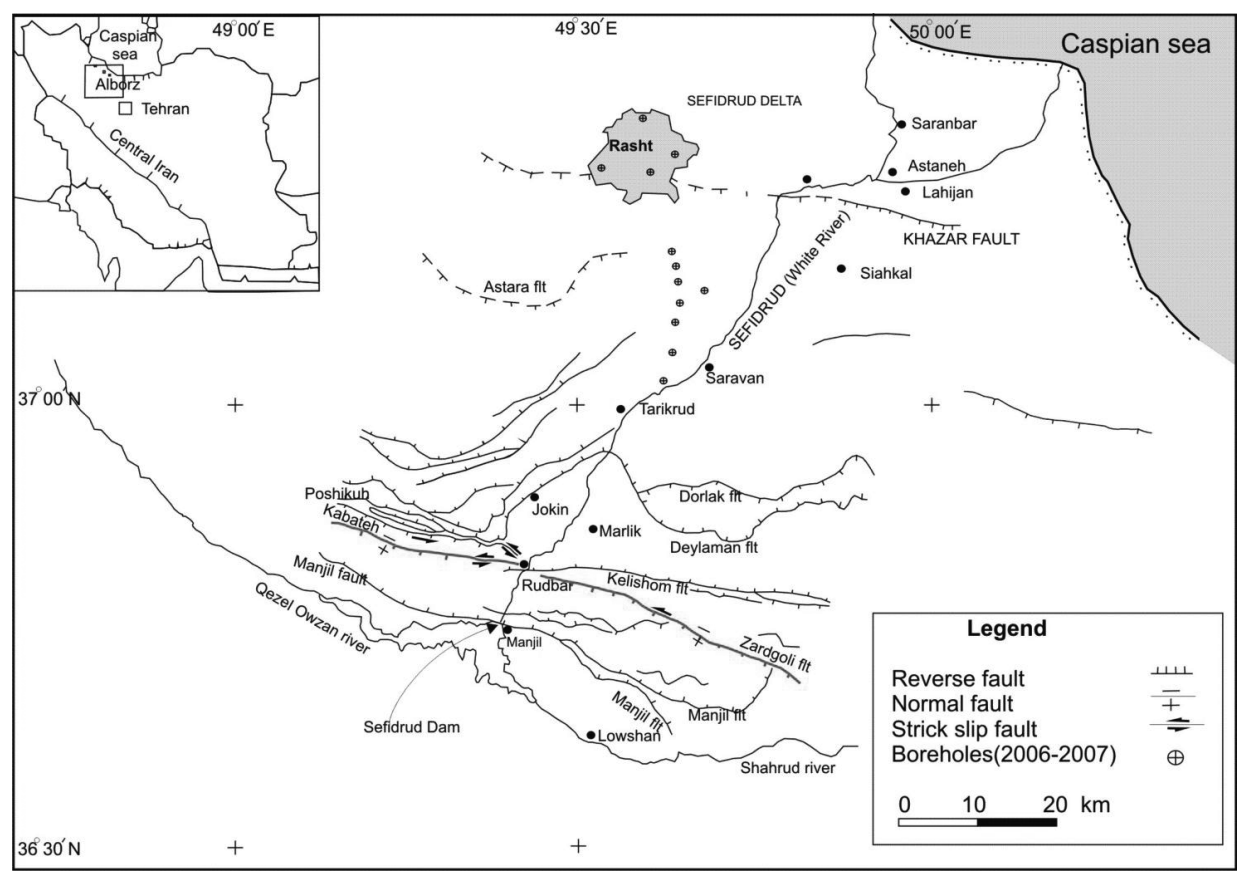

Fig. 1. Major faults, and the position of boreholes in Rasht area. 


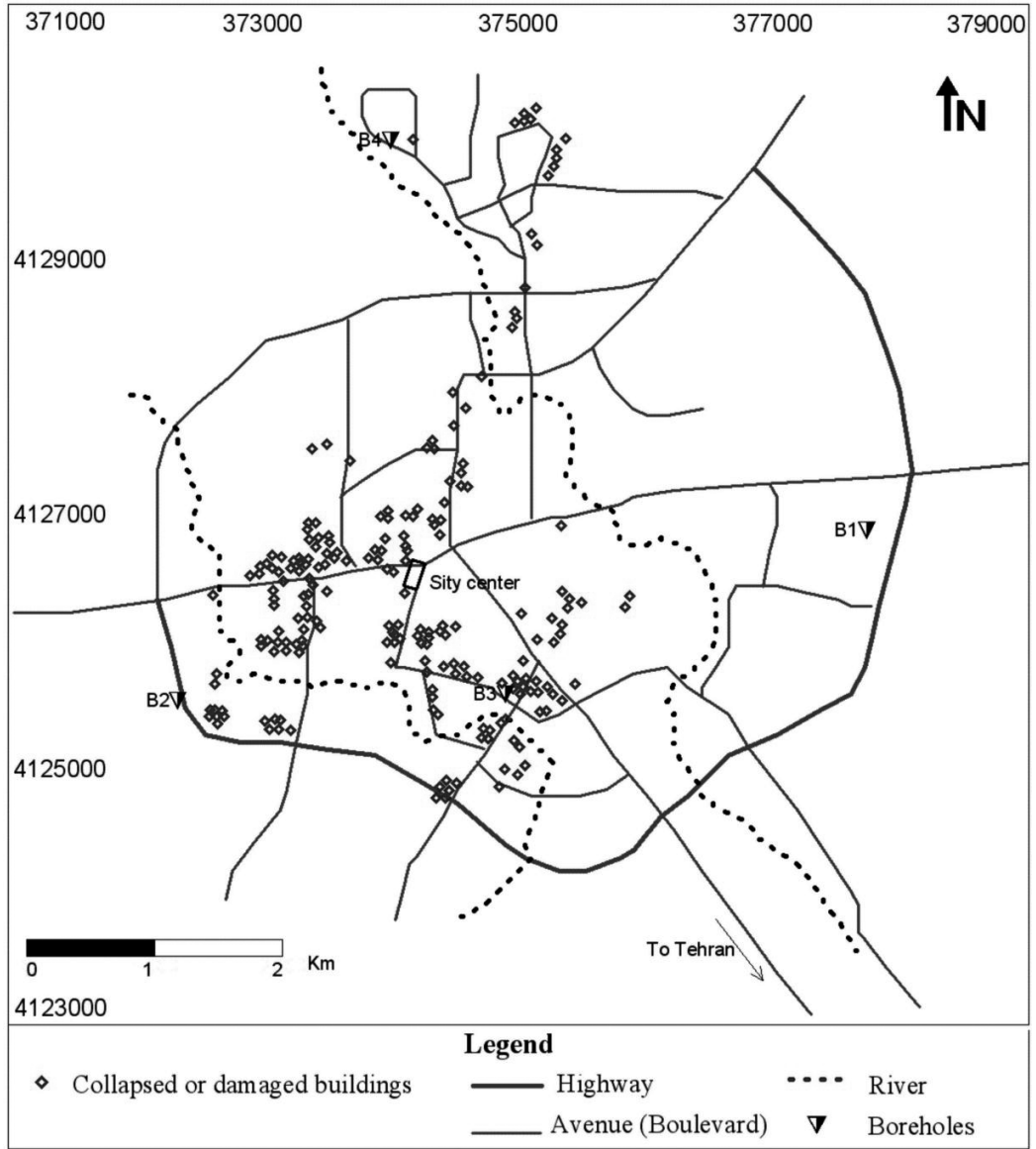

Fig. 2. Location map of destroyed or damaged buildings in Rasht city during 1990 Manjil earthquake (Natural Disaster Prevention Center, 1994).

were performed. Data of the recent study were compiled together with the results from previous studies for creating a suitable seismic database. Considering characteristics of geologic units of Rasht, this paper describes the effort to define the shear-wave velocity classification for Rasht, based on NEHRP site classes.

\section{Seismicity and geological setting of Rasht area}

Rasht is located between the Caspian coastal zone in the north and Alborz Mountains in the south. The southern part of the Caspian shores is a narrow coastal plain with an average width of about $50 \mathrm{~km}$, created by the «regional regression» of the sea, which probably once extended as far as the foot of the Alborz Mountains (Geological survey of Iran, 2004). The depth of bedrock in the city of Rasht is not known. Based on a geoelectric survey performed down to 200 $\mathrm{m}$ some 40 years ago, at $150-160 \mathrm{~m}$ depth the electric resistance drops drastically which might be either bedrock or a thick layer of over-consolidated clay. At least two water wells have been drilled down to a depth of 150-160 $\mathrm{m}$ in the urban area of Rasht. Therefore the depth of qua- 


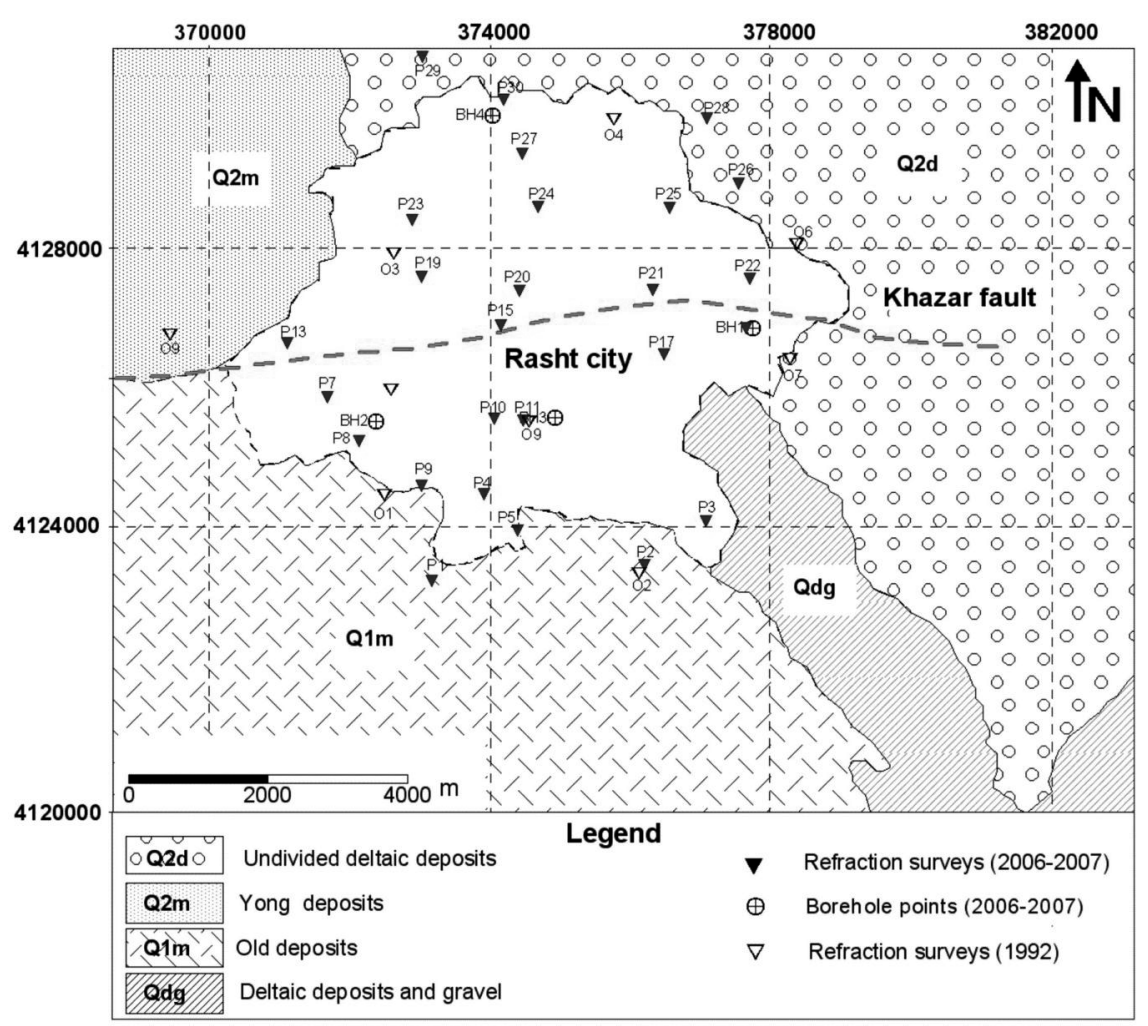

Fig. 3. Distribution of seismic profiles throughout the Rasht city.

ternary deposits in Rasht city is greater than 160 m (Haeri and Kholafaie, 1994). The tectonics of the Alborz Mountain Belt is controlled by boundary conditions, due to convergence of the Arabian and Eurasian plates probably commenced in the Cretaceous. Alborz and its associated mountain range form a continuous wall along the north of Iran. From east to the west, the width of the coastline of Caspian Sea increases where the vast Delta of Sefidrud River expands. In the Sefidrud River Delta and Rasht area on the west, the coastal plain widens to 33 $\mathrm{km}$. The important coastal features along coastlines in Rasht area is Sefidrud Delta. Intensive geological and tectonic investigations reveal the vulnerability of the region to earthquake damage. Historically a destructive Manjil earthquake on 20 June 1990 in this region caused casualties which were reported to be more than
25,000 lives. Three towns of Manjil, Rudbar and Loshan located in the epicentral area were almost demolished showing the highest casualties in these areas. The reported magnitude by USGS is Ms=7.7 and Mb=6.4 (Niazi and Bozorgnia, 1992; Berberian et al. 1992; Haeri and Kholafaie, 1994). Figure 1 shows the location of the epicenter and major towns and cities that were affected by Manjil earthquake. From a microseismal point of view Manjil was reported as the epicenter. However the aftershocks recorded in the epicentral region indicated that the epicenter was a few kilometers north of Rudbar (Haeri and Kholafaie, 1994). The surface faulting was mapped for a length of more than $80 \mathrm{~km}$ in segments (Berberian and Qorashi, 1991). The June 1990 earthquake caused widespread damage in areas within a one hundred kilometer radius of the epicenter, near the city of Rasht and about 


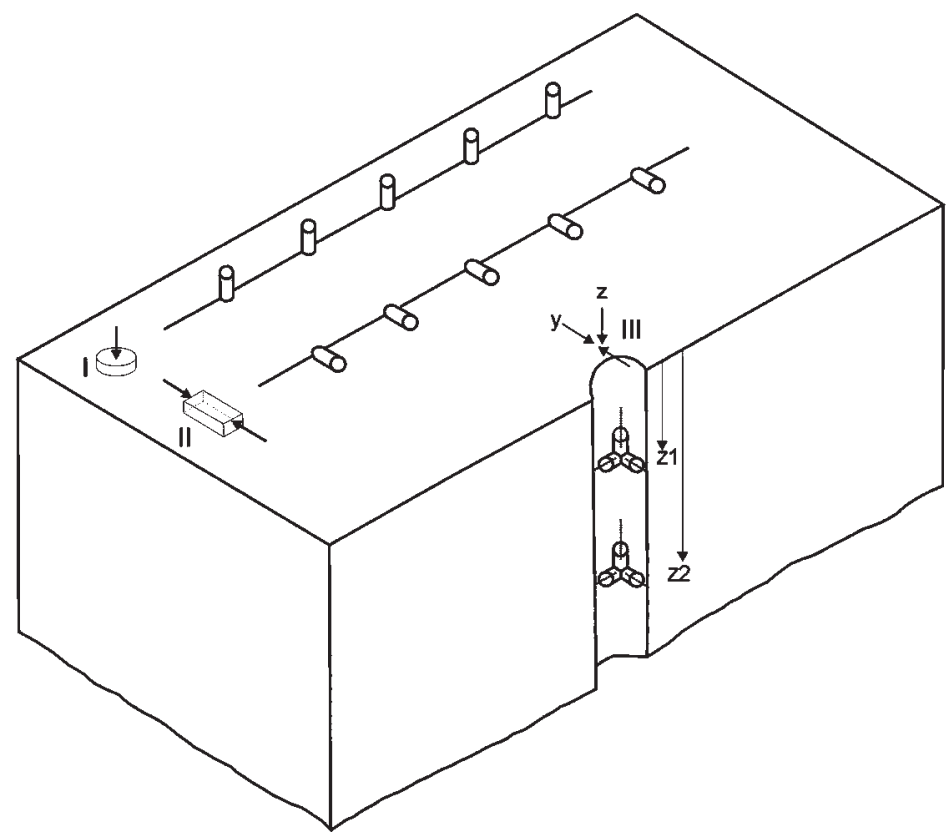

Fig. 4. Schematic of seismic Profiles: I-refraction P-wave, II-refraction S-wave and III- downhole.

two hundred kilometers northwest of Tehran.

The study area is the cover territory of Rasht city, bounded between longitudes of $49^{\circ} 32^{\prime}-$ $49^{\circ} 39^{\prime} \mathrm{E}$ and latitudes of $37^{\circ} 14^{\prime}-37^{\circ} 19^{\prime} \mathrm{N}$ (fig. 1). Geologically, the city of Rasht is located in the intercept of 4 different types of Pleistocene (Q1m, Qdg) and Holocene (Q2m, Q2d) sediments (fig. 3). Rasht city, built on Quaternary sediments, consists of old marine $(\mathrm{Q} 1 \mathrm{~m})$ in the south, deltaic (Qdg) in the southeast, undivided deltaic sediments with gravel (Q2d) in north and east and young marine (Q2m) deposits in the northwest. The boundaries of these sediments are not separated in urban territory of Rasht city (fig. 3).

The damage report indicates that the rate of damage was different in the region. In the epicentral region, there were mainly one- and twostory buildings, which have been demolished or damaged, mainly in Manjil, Rudbar and Loshan towns. The epicenter of 1990 earthquake located about $60 \mathrm{~km}$ southwest of Rasht (fig. 1). In the city of Rasht, long-period ground motion appeared to cause the partial or total collapse of many mid-rise buildings. In Rasht most of the four- to eight-story buildings in center and south of the city were damaged and at least three eight-story buildings were completely demolished. A seven-story steel frame building was deviated from vertical position and a fivestory reinforced concrete building collapsed.

An elevated concrete water tank, two-thirds full at the time of the earthquake, in central part of the city (next to BH3) was completely demolished. The tank was $46 \mathrm{~m}$ high and had a volume of $1500 \mathrm{~m}^{3}$. The structure had a reinforced concrete shaft of $6 \mathrm{~m}$ diameter and a prestressed concrete tank. Two other elevated water tanks with $2500 \mathrm{~m}^{3}$ capacity (next to BH1 and $\mathrm{BH} 2$ ) with $50 \mathrm{~m}$ height, empty at the time of earthquake, were undamaged and only tension cracks appeared at the base of their shafts. Figure 2 shows the location of destroyed or damaged structures in Rasht during 1990 Manjil-Rudbar earthquake (Natural Disaster Prevention Center, 1994). 


\section{Data acquisition and interpretation}

Data of pre 1990 seismic survey include nine seismic profiles and twenty five boreholes without any downhole survey, retrieved from archive of Housing Foundation Organization of Iran. As part of national geotechnical and seismological survey program, 12 downhole surveys, $26 \mathrm{P}$ and $26 \mathrm{~S}$ refraction seismic surveys were performed during 2006-2007 in the Rasht region, mainly for investigating possibilities for strengthening the city water supply system. Four of the boreholes are located in the city of Rasht. The other eight, located $20 \mathrm{~km}$ south of the city, are drilled in deltaic sediments (fig. 1). Depths of boreholes are around $50 \mathrm{~m}$. Both $\mathrm{P}$ and $\mathrm{S}$ downhole tests were carried out down to $30 \mathrm{~m}$ depth. Figure 3 shows the location of all seismic profiles in the study area. These locations were selected based on limitation factors such as population density, land conditions and access permits.

The main equipment and accessories used for the field work included 24-channel seismographs, vertical and horizontal geophones, and 3-component downhole geophones. The $\mathrm{P}$ and $\mathrm{S}$-wave seismic profiles, distributed through Rasht city considering the space constraint and limitations on using explosive sources. Due to constant raining the measurements were carried out in muddy fields. The $\mathrm{P}$ and $\mathrm{S}$-wave refraction profiles performed in linear pattern. The spacing between geophones selected $2 \mathrm{~m}$ to $4 \mathrm{~m}$ and offset range of $10 \mathrm{~m}$ to $30 \mathrm{~m}$. The lengths of profiles were different due to space constraints. Length of profiles considering offsets was in range of 86 to $106 \mathrm{~m}$. A sledge hammer of 8 to $12 \mathrm{~kg}$ (equipped with a trigger element) was used as the source.

In Rasht the city noise level is considerable due to car and truck traffics, high water table surface and atmospheric conditions. In order to improve the signal to noise ratio $(\mathrm{S} / \mathrm{N})$, an average of ten hammer blows were stacked for each record. For P-wave profiles, vertical hit on steel plate and for S-wave profiles, horizontal hit on special I-beam steel were used. The schematic picture of $\mathrm{P}$ - and $\mathrm{S}$-wave profiles and downhole tests is presented in fig. 4. Data were recorded with blows in opposite directions to allow for
Table I. NEHPR site classes based on Vs(30), (BSSC, 2001).

\begin{tabular}{cc}
\hline \hline Site class & Range of Vs(30) \\
\hline A & $1500<\mathrm{Vs}(30)$ \\
B & $760<\mathrm{Vs}(30)<1500$ \\
C & $360<\mathrm{Vs}(30)<760$ \\
D & $180<\mathrm{Vs}(30)<360$ \\
E & $\mathrm{Vs}(30) \leq 180$ \\
\hline
\end{tabular}

subtracting the records to further reduce $\mathrm{P}$ wave interference and provide additional $\mathrm{S} / \mathrm{N}$ enhancement of the SH-waves.

$\mathrm{P}$ - and $\mathrm{S}$-wave sources were positioned in 1 to $2 \mathrm{~m}$ of boreholes. Three component downhole geophone pulled up from $30 \mathrm{~m}$ depth and in every two meters data were recorded in three channels of a 24-chanel seismograph from vertical and horizontal hit. Figures $5 \mathrm{a}$ and $5 \mathrm{~b}$ present $\mathrm{P}$ - and $\mathrm{S}$-wave seismograms of $\mathrm{BH} 1$ respectively, with records of first arrival times. Figures $5 c$ and $5 d$ illustrate primary $S$ wave seismograms of left and right hit, showing 180 phase difference of S-wave. Figure $5 b$ is constructed by subtracting records in figs. $5 \mathrm{c}$ and $5 \mathrm{~d}$. The first arrival times of the $\mathrm{P}$ and $\mathrm{S}$-waves extracted from figs. 5a and 5b. The interval velocity between $Z_{1}$ and $Z_{2}$ depths is calculated from eq. (3.1):

$$
V=\frac{Z_{2}-Z_{1}}{\Delta t_{0}}=\frac{2}{\Delta t_{0}}
$$

In this equation $Z_{1}$ and $Z_{2}$ are two sequential measuring depths from surface. $D \mathrm{t}_{0}$ is time difference of corrected first arrivals in two sequential depths. The corrected first arrival times calculated from equation (3.2)

$$
t_{0}=t_{Z} / \sqrt{1+(l / Z)^{2}}
$$

$t_{Z}$ is the first arrival times and $l$ is the distance between source and borehole (Gorynov, 1992). Pand $\mathrm{S}$-wave velocities in $\mathrm{BH} 1$ to $\mathrm{BH} 4$ are presented in table III. The interval velocities in boreholes are illustrated in fig. 6. Geologically, the city of Rasht is located at the intercept of 4 different 

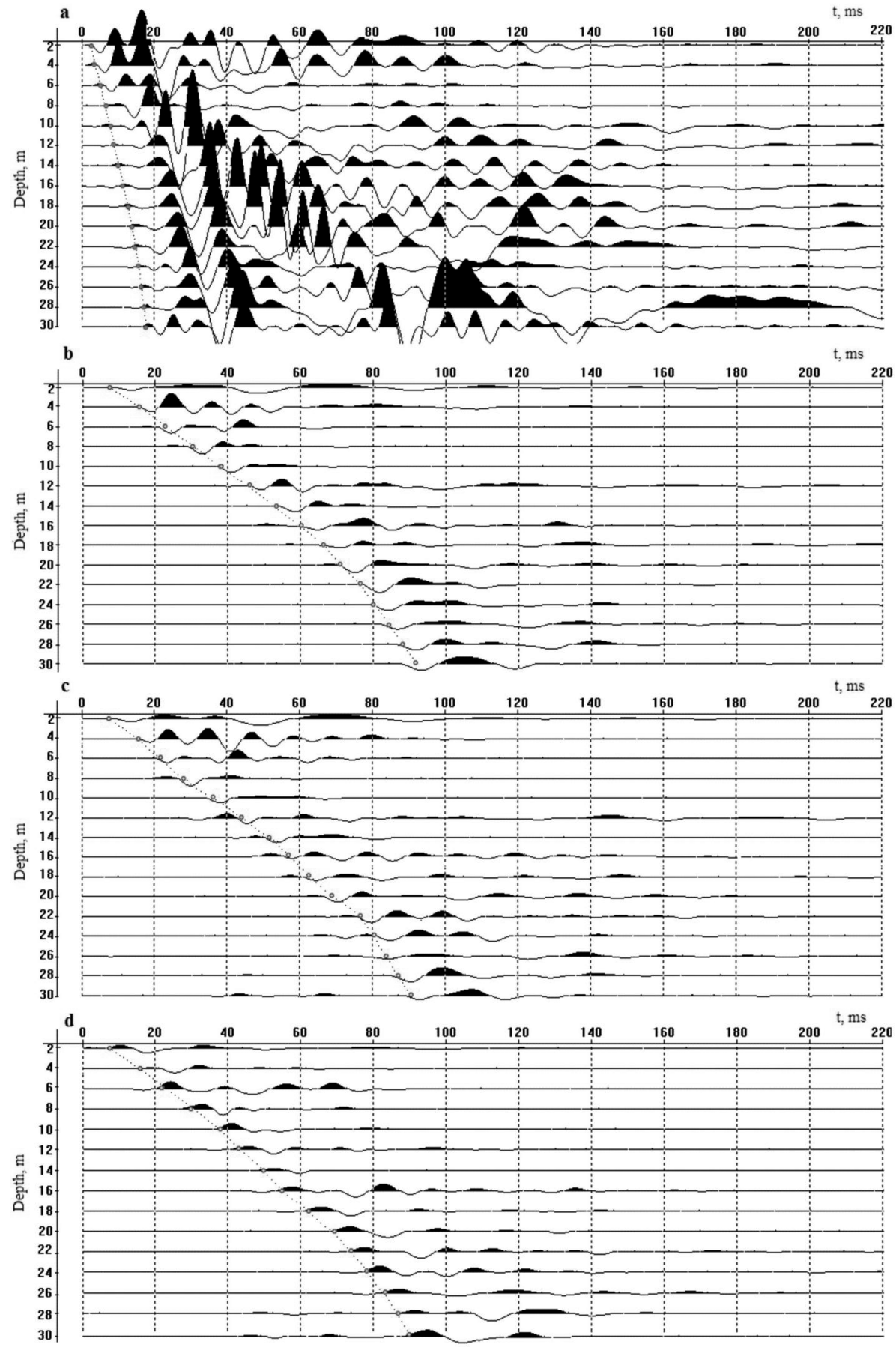

Fig. 5. P and S-wave seismograms in borehole BH1. 
Table II. Seismic profiles and site classification in Rasht city.

\begin{tabular}{ccccc}
\hline Unit & $\begin{array}{c}\text { No. of Seismic } \\
\text { refraction tests }\end{array}$ & No. of downhole tests & $\bar{V} s(30, \mathrm{~m} / \mathrm{s}$ & $\begin{array}{c}\text { NEHRP } \\
\text { site classification }\end{array}$ \\
\hline Q1m & 13 & 2 & 314 & $\mathrm{D}$ \\
Q2m & 5 & 200 & $\mathrm{D}$ \\
Q2d & 14 & 2 & 293 & $\mathrm{D}$ \\
Qdg & 2 & 234 & $\mathrm{D}$ \\
\hline
\end{tabular}

Table III. Interval S-wave and P-wave velocities in boreholes.

\begin{tabular}{ccccccccc}
\hline \hline \multirow{2}{*}{ Depth,m } & \multicolumn{2}{c}{ BH1 } & \multicolumn{2}{c}{ BH2 } & \multicolumn{2}{c}{ BH3 } & \multicolumn{2}{c}{ BH4 } \\
\cline { 2 - 8 } & Vs, m/s & Vp, m/s & Vs, m/s & Vp, m/s & Vs, m/s & Vp, m/s & Vs, m/s & Vp, m/s \\
\hline $2-2$ & 285 & 780 & 170 & 700 & 225 & 741 & 250 & 800 \\
$4-6$ & $298 \mathrm{a}$ & 1486 & 174 & 1480 & 225 & 750 & 270 & 1020 \\
$6-8$ & 312 & 1586 & 198 & 1494 & 237 & 800 & 329 & 1400 \\
$8-10$ & 304 & 1585 & 186 & 1494 & 206 & 1413 & 320 & 1410 \\
$10-12$ & 322 & 1586 & 220 & 1594 & 237 & 1550 & 370 & 1410 \\
$12-14$ & 322 & 1600 & 212 & 1700 & 206 & 1600 & 365 & 1420 \\
$14-16$ & 322 & 1587 & 228 & 1709 & 225 & 1600 & 370 & 1449 \\
$16-18$ & 344 & 1695 & 212 & 1720 & 225 & 1547 & 360 & 1493 \\
$18-20$ & 420 & 1835 & 228 & 1750 & 296 & 1565 & 375 & 1587 \\
$20-22$ & 423 & 1980 & 374 & 1818 & 427 & 1709 & 430 & 1818 \\
$22-24$ & 530 & 2130 & 390 & 1820 & 400 & 1575 & 440 & 1820 \\
$24-26$ & 534 & 2150 & 390 & 1835 & 426 & 1626 & 440 & 1835 \\
$26-28$ & 540 & 2150 & 390 & 1835 & 435 & 1695 & 440 & 1835 \\
$28-30$ & 541 & 2160 & 390 & 1835 & 476 & 1695 & 440 & 1835 \\
Avrage & 364 & & 250 & & 273 & & 361 & \\
\hline
\end{tabular}

types of Pleistocene (Q1m, Qdg) and Holocene (Q2m, Q2d) sediments (fig. 3). Study of 29 (4 recent and 25 from 1991) borehole logs indicates that the sedimentary deposits which Rasht is built on are heterogeneous. It is composed of clay, silt, sand and gravel. Due to differences in sedimentation trends, age, heterogeneity of sediments and elevated water table, an anisotropic media is cre- 

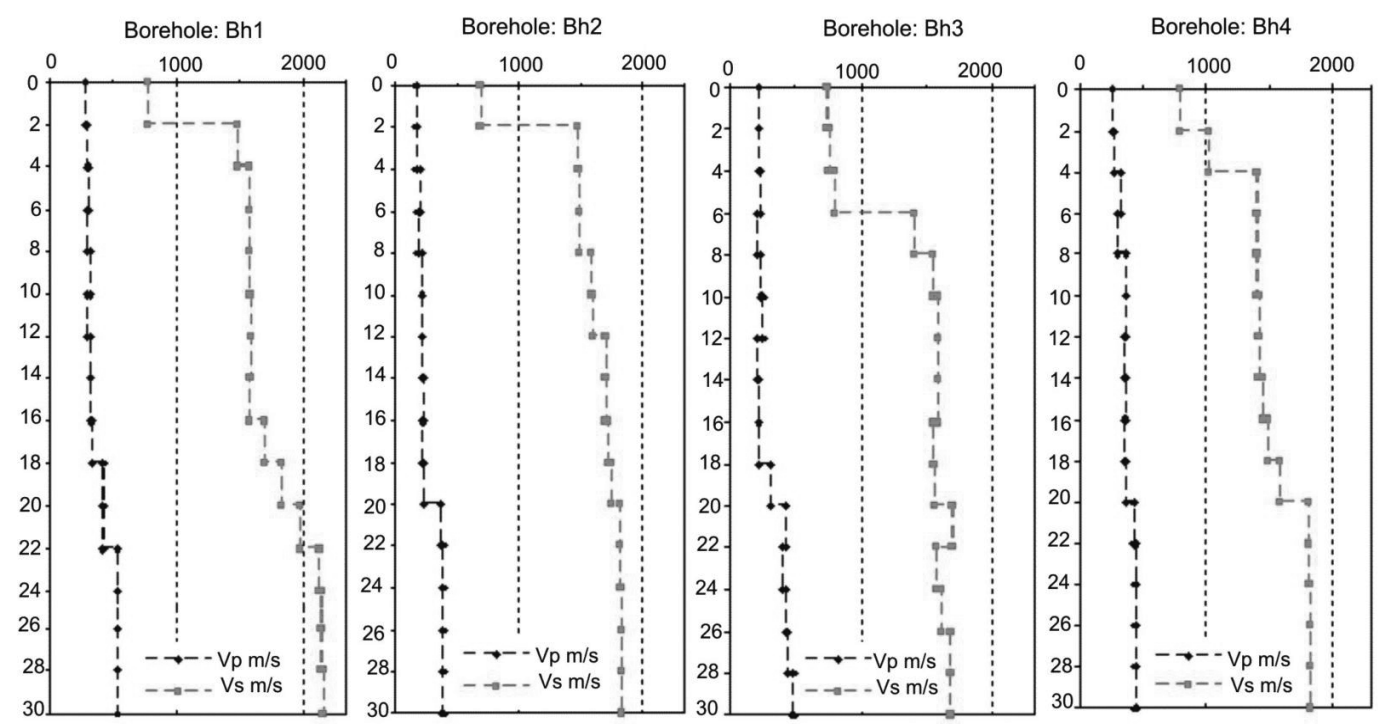

Fig. 6. S-wave and P-wave velocities in boreholes throughout Rasht city.

ated. The response of such an environment to wave propagation is in gradient form (continuous medium). In continuous medium, refracted seismic waves according to the principle of Fermat (Sheriff and Geldart, 1985) are recorded as the first arrivals. In this case the Herglots-Withchers (Gorynov, 1992) inversion method was used for interpretation of time-distance curve. In the Herglots-Withchers method, for each point $\left(x_{\mathrm{n}}\right)$ apparent velocity $\left(V_{\mathrm{n}} *\right)$ is calculated from time-distance curve, which belongs to maximum penetration depth $\left(z_{\mathrm{m}}\right)$ of each seismic ray, obtained from eq. (3.3).

$$
\begin{aligned}
& z_{m}\left(x_{n}\right)=\frac{\Delta x}{\Pi} \sum_{x_{i}=0}^{x_{i}=x_{n}} 2.3026 \lg \left(\frac{V^{*}\left(x_{n}\right)}{V^{*}\left(x_{i}\right)}+\right. \\
& \left.+\sqrt{\left(\frac{V^{*}\left(x_{n}\right)}{V^{*}\left(x_{i}\right)}\right)^{2}-1}\right)
\end{aligned}
$$

In equation (3.3) $\Delta x$ is distance between geophones.

In layered condition, when the velocity of wave in bottom layer is less than in the top layer, the head wave is created. In this condition the intercept time method (Sheriff and Geldart, 1985) was used for interpretation of the timedistance curve.
Shear wave velocities in each profile are shown in table IV. The Sssoft software from Moscow state university was is used for calculations.

In Rasht city, sediments are not exposed; they lacked index fossils and have not been dated by radiogenic techniques. The velocity of $\mathrm{P}-$ and S-waves depends on porosity, matrix, moisture and saturation of sediments. In sandy and sandy-clay layers with constant porosity, while the moisture content is less than saturation condition, with moisture increase, $\mathrm{P}$-wave velocity remain unaffected, while in saturation point $\mathrm{P}$ wave velocity shows an abrupt increase. The velocity of S-wave remains unaffected in unsaturated and saturated condition (Gorynov, 1992). It must be noted that due to decrease of cohesion in saturated media, S-wave velocity will decrease slightly.

The water table in Rasht is between 1 to $6 \mathrm{~m}$ below the surface. Therefore it will be possible to determine the boundary of sedimentary units by $\mathrm{P}$-wave velocity variation map. Figures 7 and 8 show the variations of $\mathrm{P}$-wave velocity in Rasht underneath and above the water table respectively.

Different grain size of the sedimentary units, sedimentation trends, age of sediments, 
Table IV. S-wave velocities in refraction profiles.

\begin{tabular}{|c|c|c|c|c|c|c|c|c|c|}
\hline Profiles & $\mathrm{h} 1, \mathrm{~m} / \mathrm{s}$ & $\mathrm{V} 1, \mathrm{~m} / \mathrm{s}$ & $\mathrm{h} 2, \mathrm{~m}$ & $\mathrm{~V} 2, \mathrm{~m} / \mathrm{s}$ & h3, m & $\mathrm{V} 3, \mathrm{~m} / \mathrm{s}$ & $\mathrm{h} 4, \mathrm{~m}$ & $\mathrm{~V} 4, \mathrm{~m} / \mathrm{s}$ & $\mathrm{Vs} 30, \mathrm{~m} / \mathrm{s}$ \\
\hline $\mathrm{P} 1$ & 2 & 120 & 8 & 250 & 20 & 250 & & & 233 \\
\hline $\mathrm{p} 2$ & 6 & 170 & 7 & 270 & 17 & 300 & & & 254 \\
\hline $\mathrm{P} 3$ & 2 & 130 & 6 & 270 & 22 & 270 & & & 252 \\
\hline $\mathrm{P} 4$ & 4 & 216 & 11 & 324 & 15 & 324 & & & 304 \\
\hline P5 & 4 & 150 & 8 & 250 & 18 & 250 & & & 230 \\
\hline p7 & 2.5 & 230 & 9.5 & 470 & 18 & 470 & & & 432 \\
\hline P8 & 4 & 185 & 20 & 320 & 6 & 400 & & & 303 \\
\hline $\mathrm{p} 9$ & 7 & 400 & 3 & 550 & 20 & 550 & & & 506 \\
\hline p10 & 4 & 200 & 12 & 320 & 14 & 450 & & & 339 \\
\hline p11 & 3 & 110 & 4 & 210 & 9 & 400 & 14 & 450 & 300 \\
\hline p13 & 4 & 120 & 7 & 280 & 19 & 280 & & & 238 \\
\hline p15 & 4 & 160 & 9 & 260 & 17 & 450 & & & 308 \\
\hline p17 & 2.5 & 160 & 11.5 & 230 & 11 & $200-220$ & 5 & 260 & 218 \\
\hline p18 & 6 & 400 & 10 & 500 & 14 & 614 & & & 519 \\
\hline p19 & 5 & 140 & 8 & 250 & 17 & 250 & & & 221 \\
\hline $\mathrm{p} 20$ & 3 & 120 & 9 & 200 & 18 & 220 & & & 198 \\
\hline $\mathrm{p} 21$ & 4 & 115 & 8 & 200 & 18 & 250 & & & 204 \\
\hline p22 & 5 & 200 & 15 & 460 & 10 & 614 & & & 406 \\
\hline $\mathrm{p} 23$ & 4 & 110 & 10 & 210 & 16 & 250 & & & 203 \\
\hline $\mathrm{p} 24$ & 4 & 130 & 6 & 265 & 9 & 320 & 11 & 450 & 283 \\
\hline p25 & 7 & 100 & 9 & 270 & 14 & 270 & & & 193 \\
\hline $\mathrm{p} 26$ & 4 & 95 & 12 & 419 & 14 & 419 & & & 288 \\
\hline p27 & 3 & 135 & 8 & 155 & 19 & 315 & & & 224 \\
\hline $\mathrm{p} 28$ & 6 & 380 & 4 & 560 & 20 & 560 & & & 512 \\
\hline p29 & 4 & 100 & 16 & 420 & 10 & 450 & & & 299 \\
\hline p30 & 6 & $120-175$ & 5 & 250 & 9 & 370 & 10 & 450 & 270 \\
\hline
\end{tabular}




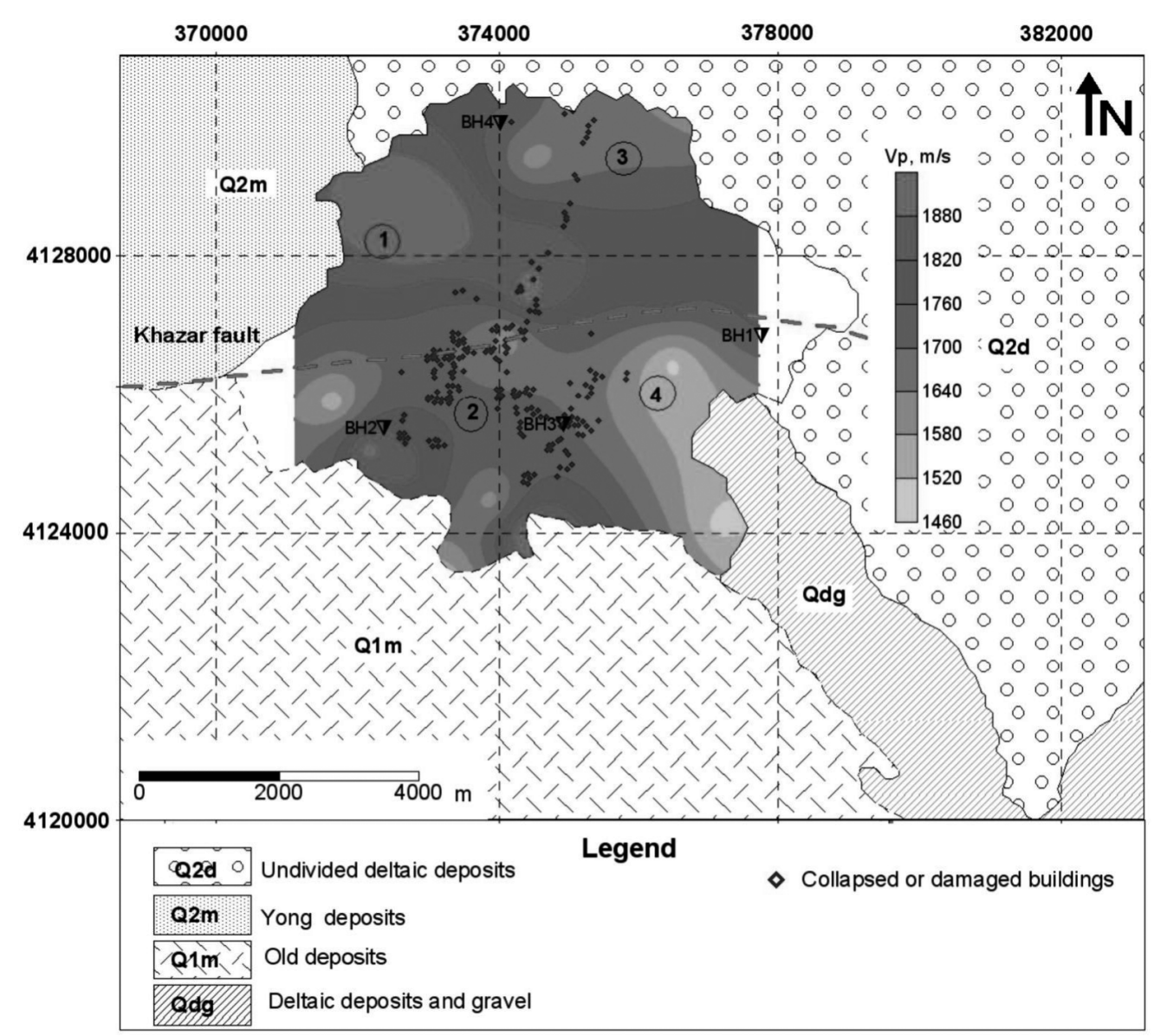

Fig. 7. Variation of $\mathrm{Vp}$ in Rasht city underneath of the water table.

ground water condition, weathering and clay contents cause variations in $\mathrm{P}$-wave velocity from $1450 \mathrm{~m} / \mathrm{s}$ up to $1900 \mathrm{~m} / \mathrm{s}$ beneath the water table surface (fig. 7). P-wave velocity varies above the water table surface from 300 to 750 $\mathrm{m} / \mathrm{s}$ (fig. 8).

There are four recognizable zones in the seismic map (figs. 7 and 8) which correlates well with the geological map. Sedimentary boundaries are well separated. Zones 1, 2, 3 and 4 correspond to sedimentary units Q2m, Q1m, Q2d and Qdg, respectively. Figure 9 shows the border of sedimentary units in the study area.

\section{Shear-wave characteristics of different zones}

In order to determine shear wave velocity distribution throughout the Rasht area, the results of 30 seismic profiles, including 26 seismic refraction and 4 downhole tests surveyed during 2006 to 2007, are compiled with the results of 9 previous studies (see table II for details). Seismic refraction survey and downhole tests were used to measure wave velocities down to depths of $30 \mathrm{~m}$. Figure 3 shows the location of all Vs measurements throughout the study area. Due to a high population density or 


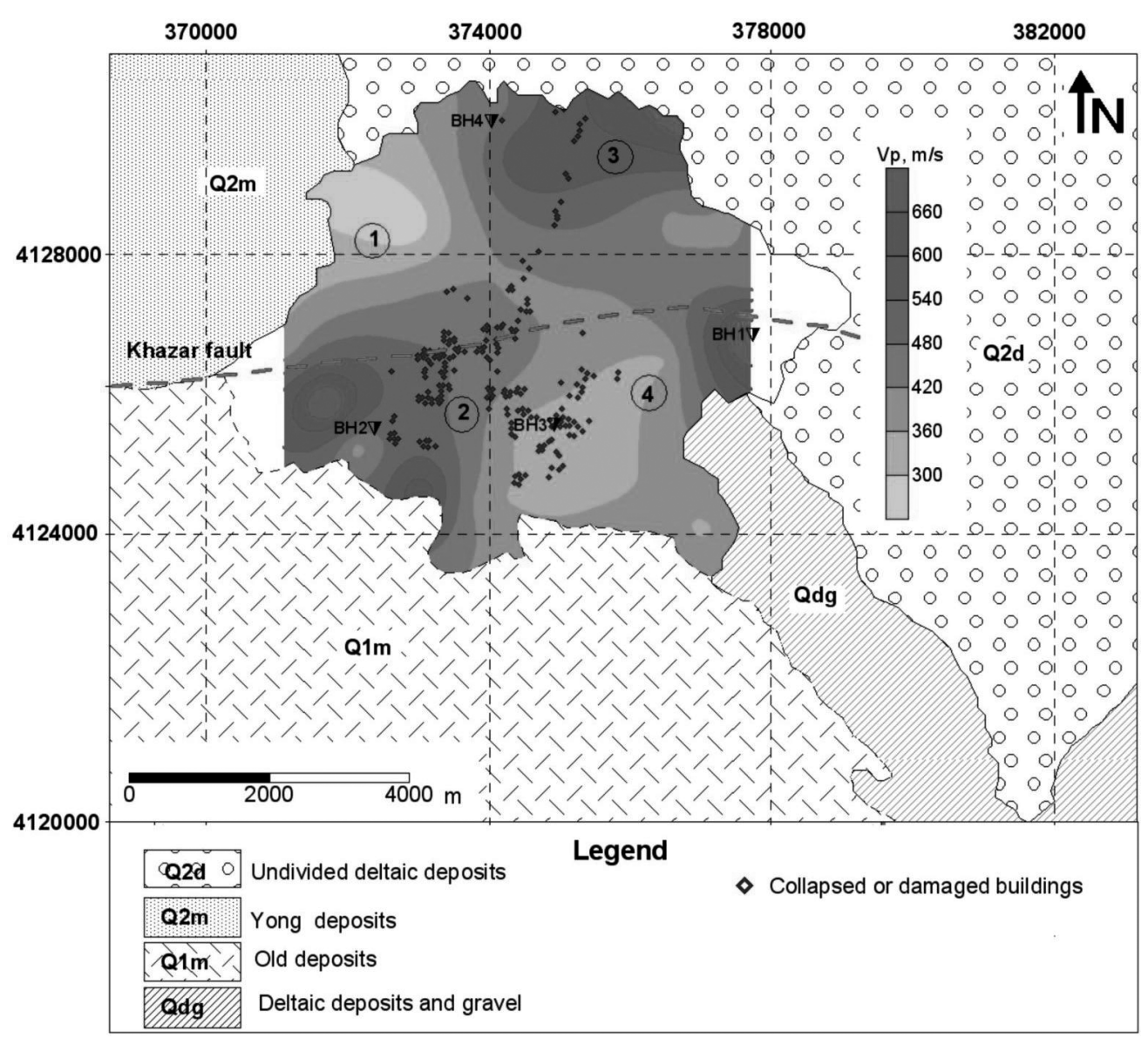

Fig. 8. Variation of Vp in Rasht city above the water table.

land conditions, measurements were carried out in a few selected locations. In order to measure $V_{\mathrm{s}}(30)$ values in the Rasht area, we utilized the following relation presented by NEHRP (BSSC, 2001):

$$
\bar{V}_{s(30)}=\sum_{i=1}^{n} d i / \sum_{i=1}^{n} d i / V s
$$

where di and Vsi are thickness and shear-wave velocity of each layer respectively, and $n$ is the number of layers down to $30 \mathrm{~m}$ depth. Based on data of refraction seismic and downhole surveys Vs profiles were prepared for all data points (fig. 3). An average of $\mathrm{Vs}(30)$ calculated from these profiles were used to develop $\mathrm{Vs}(30)$ map. The characteristics of shear-wave velocity in different geological units will be presented and discussed in the following section.

\subsection{Unit $Q 1 m$}

Unit Q1m is the old marine deposit. It constrains the south and southwest of Rasht and is of Pleistocene age (fig. 9). According to borehole logs, this unit consists of clayey gravel, silty sand, clay and gravel. A total of 15 seismic tests, including 13 refraction and 2 downhole tests were carried out in this unit (table II). The histogram of shear-wave velocity distribution 


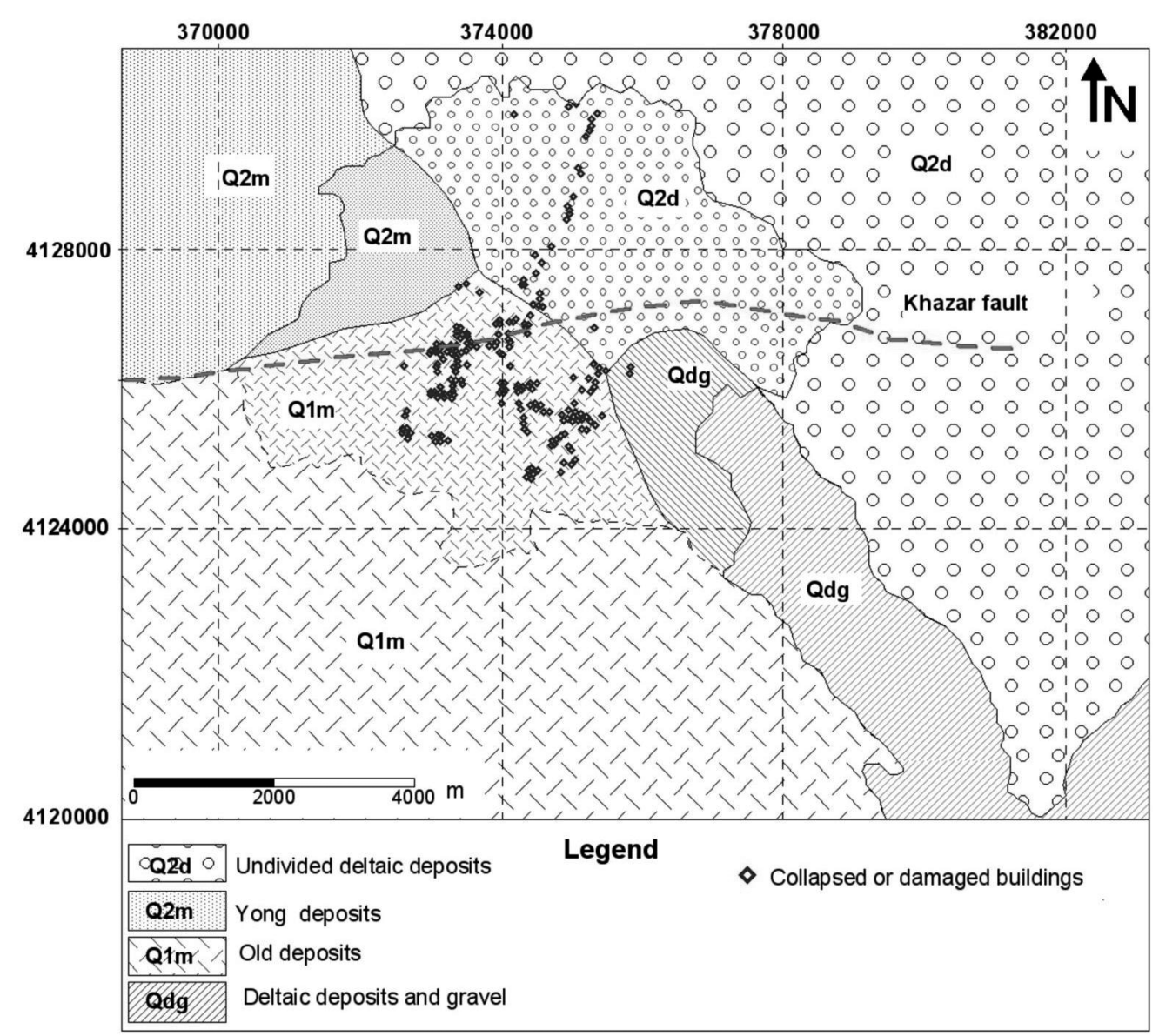

Fig. 9. The boundary of sedimentary units in study area.

for upper $30 \mathrm{~m}$ of the ground is shown in fig. 10a. The $\mathrm{Vs}(30)$ values range from 150 to 550 $\mathrm{m} / \mathrm{s}$. Based on the database, a value of $314 \mathrm{~m} / \mathrm{s}$ is calculated for $\bar{V} s$ (30 of unit Q1m (table II). This value falls in the D category of the NEHRP site classification (table I).

\subsection{Unit $Q 2 d$}

This unit is located in the north and east of the study area (fig. 9). Borehole data show that the sequence of materials in this unit are clayey gravel, silty sand, clay, stiff silt and gravel to a depth of $50 \mathrm{~m}$. A total of 14 seismic refraction tests and 2 downhole tests were performed in this unit (table II). Figure 10b presents the histogram of shear-wave velocity distribution for Vs(30) of unit Q2d. This figure shows that the values of $\mathrm{Vs}(30)$ range from 150 to $550 \mathrm{~m} / \mathrm{s}$. On the basis of the database, the value of $\bar{V} s(30$ for this unit is $293 \mathrm{~m} / \mathrm{s}$ (table II). Based on this value, category D of NEHRP site classification (table I) can be attributed to unit Q2d.

\subsection{Unit $Q 2 m$}

A small part of the urban territory (about 4$5 \mathrm{~km}^{2}$ ) of Rasht city in the northwest is located 

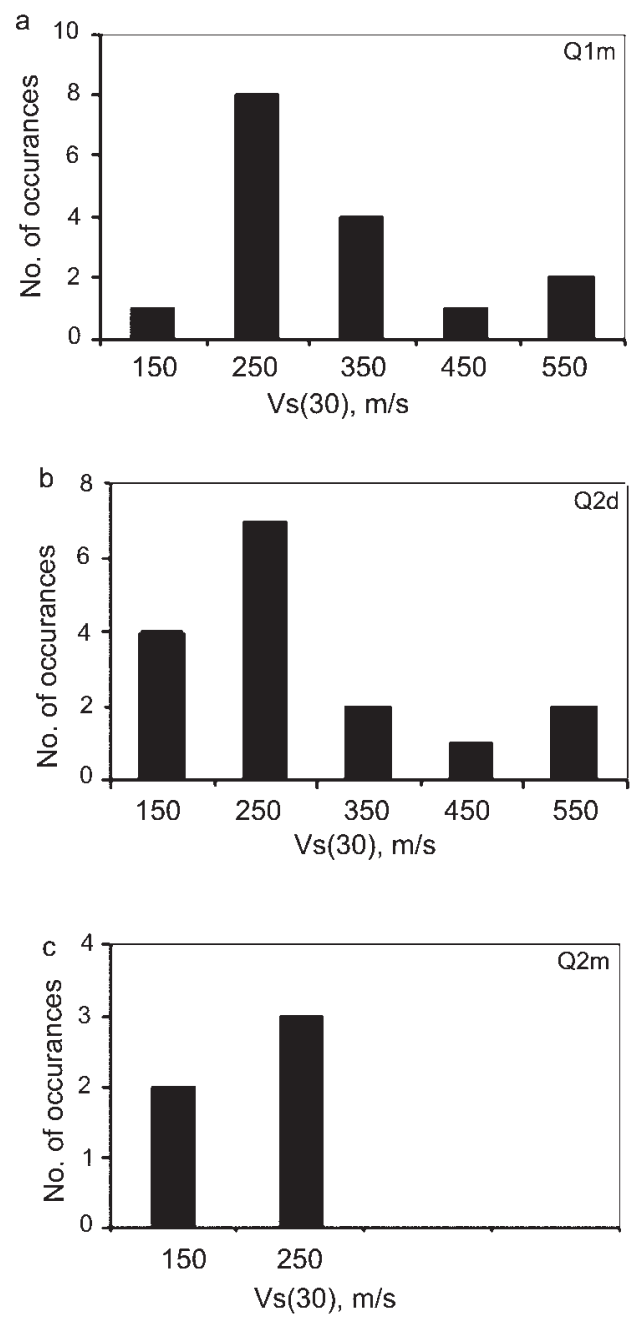

Fig. 10a-c. Histogram of $\mathrm{Vs}(30)$ for (a) unit Q1m, (b) unit Q2d and (c) unit Q2m.

in the young marine deposits $(\mathrm{Q} 2 \mathrm{~m})$. This unit is mainly composed of soft clay and sand, used for rice farming, which caused serious difficulties during seismic tests. A total of 5 seismic tests were carried out in this unit (table II). The values of $\mathrm{Vs}(30)$ range from 150 to $250 \mathrm{~m} / \mathrm{s}$. On the basis of the existing data, the value of $\bar{V} s(30$ for this unit is $200 \mathrm{~m} / \mathrm{s}$ (table II). Therefore, category D of NEHRP site classification (table I) can be attributed to the unit Q2m (table II).

\subsection{Unit Qdg}

The south east of the urban territory (about $4 \mathrm{~km}^{2}$ ) of Rasht city is located on deltaic sediments of Pleistocene (Qdg). This part of the city with a large population created serious access limitation. In Rasht urban territory, 2 seismic tests were carried out in this unit. A total of 8 downhole tests were carried out in this unit, $20 \mathrm{~km}$ from Rash city. The values of Vs(30) in this unit vary from 200 to $250 \mathrm{~m} / \mathrm{s}$. On the basis of the existing data, the value of $\bar{V} s(30$ for this unit is $234 \mathrm{~m} / \mathrm{s}$ as shown in table II. Based on this value, category D of NEHRP site classification (table I) can be attributed to unit Qdg.

\section{Construction of the S-wave velocity and AHSA maps}

In order to construct a shear-wave velocity map of Rasht, the locations of all the $\mathrm{Vs}(30)$ measurements are plotted on a digitized geological map, overlaid by contours of Vs(30). Figure 11 presents the distribution of $\operatorname{Vs}(30)$ in Rasht, based on the NEHRP site classification (table I). This figure shows that Rasht city is mainly placed on sediments of D category. Part of Rasht is placed on recent marine deposits $(\mathrm{Q} 2 \mathrm{~m})$ in the north-west and on deltaic deposit in the southeast falls in D category. The southern area of Rasht is placed on old marine deposit (Q1m) with $\mathrm{D}$ and $\mathrm{C}$ categories. Materials of north Rasht mainly fall in category $\mathrm{D}$ and in some part in categories $\mathrm{C}$ and $\mathrm{E}$. In the urban territory of Rasht city, with an area of $40 \mathrm{~km}^{2}$, shear-waves velocities were measured along 39 seismic profiles (fig. 3 ). The average of one profile per square kilometer is appropriate for the construction of a map. Therefore, this map provides a good approximation of shallow material properties that can be used alone, or in conjunction with other factors to calculate seismic amplifications and seismic hazards. Rapid assessment of earthquake damage may also benefit from this map based on shearwave velocity (Wald and Mori, 2000).

There are different techniques for evaluating effects of site condition on amplification factor. Shima (1978) showed that the amplification has a linear relation with the shear wave 


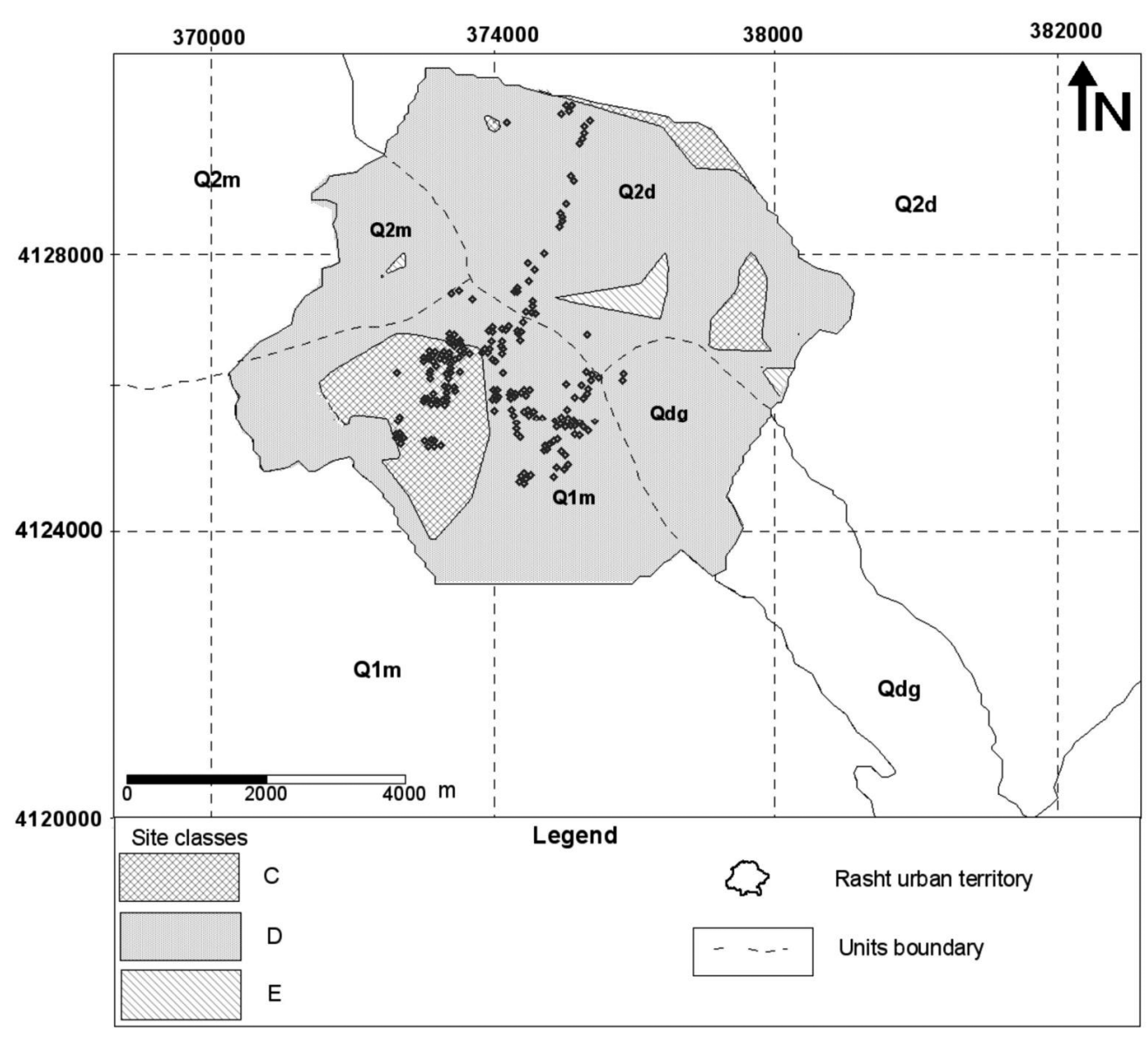

Fig. 11. Distribution of in Rasht.

velocity ratio of surface layer and bedrock. Midorikawa (1978) and Borcherdt et al. (1991) have shown that the average shear wave velocity for upper $30 \mathrm{~m}$ of the ground shows significant relation with local site amplification. Borcherdt et al. (1991) equation is:

$$
\left\{\begin{aligned}
\text { AHSA } & =700 / V s(30) \text { for weak motion } \\
& =600 / V s(30) \text { for strong motion }
\end{aligned}\right.
$$

AHSA is average horizontal spectral amplification in 0.4 to 2 seconds periods and $\mathrm{Vs}(30)$ is shear wave velocity in $30 \mathrm{~m}$ depth. The aver- age horizontal spectral amplification in Rasht city, calculated by eq. 5.1 (for weak motion), is presented in fig. 12, indicating higher amplification in the east and north compared with the center and south of Rasht city. It is supported with geological data, as bedrock in east and north is young sediments, while in center and south is older sediments. The damaged buildings in Rasht city were mainly four - to eightstory buildings. The natural periods of these buildings are calculated by eq. 5.2 (Natural Disaster Prevention Center, 1994).

$$
T=C \cdot H^{3 / 2}
$$


$\mathrm{H}$ is building height $(\mathrm{m})$, and $\mathrm{C}$ is a constant factor, i.e. 0.08 for steel frame and 0.07 for reinforced concrete buildings. Calculation shows that natural period of building for four- to eightstory buildings $(\mathrm{H} \approx 10-20 \mathrm{~m})$ is about 0.4 to 0.8 seconds.

\section{Discussion}

This investigation identified the boundaries of different sedimentary units underneath Rasht city. The marine sediments of Pleistocene age (Q1m) show extensive lateral variations (fig. 7).

The average horizontal spectral amplification map (fig. 12) indicates that amplification factors in east and north are higher than the center and south of the city. This conclusion is supported by geological observations as in the north and east basement composed of recent sediments, while in the south and center it is composed of the old alluvium.

During earthquakes, the vibration modes of the ground matched with the natural periods of the buildings of more than four-story. Most mid-rise buildings either collapsed or were damaged compared with short-rise buildings. These buildings mainly located in the center and south of the city on local lateral unconformities of the old marine (Q1m) sediments (fig. 7). Most damage was due to collisions between short-rise and mid-rise buildings, in which midrise building damage was significant. It can be inferred that, due to vertical and horizontal heterogeneity in Q1m unit, structures experienced amplification with different periods and building collision caused damage to most structures.

Although most mid-rise buildings located north of Rasht city in a linear trends were damaged due to amplification, these buildings were also oriented perpendicular to Khazar fault trend (fig. 9). Therefore Khazar fault may also have contributed to increasing damage to these buildings.

It can be inferred that the heterogeneity of old marine sediments $(\mathrm{Q} 1 \mathrm{~m})$ in Rasht is one of the major factors which might have contributed significantly to local amplification of ground motions during the 1990 Manjil earthquake.
Khazar fault crosses Rasht city and separates old sedimentary units of Pleistocene age (Qdg and Q1m) in the south from more recent sediments (Q2d and Q2m) in the north. Such an unconformity underneath Rasht should be considered in the seismic hazard map of the city.

The results of site-condition studies can be used for land-use planning and strengthening of the existing structures against future earthquakes. Shear-wave velocity in different deposits is one of the parameters that can be used for the evaluation of site conditions and their influence on bedrock motion.

\section{Summary and conclusions}

This paper presents the shear-wave velocity (Vs) characteristics for the various sedimentary units throughout Rasht and the boundaries of different geological units and their lateral heterogeneity.

The Rasht plain was further divided into four units. The physical properties of different geological units were studied in depth. The distribution of shear-wave velocity to $30 \mathrm{~m}$ for each of the units was presented and the average shear-wave velocity to $30 \mathrm{~m}$ depth was used to develop site categories for Rasht.

Finally, a map of site conditions in Rasht constructed based on NEHRP classifications. The following conclusions are also drawn based on this study:

1) Considering good coverage of seismic profiles, boundaries of sedimentary units are recognized.

2) The marine sediments of Pleistocene age (Q1m) has extensive lateral variation and location of destroyed or damaged buildings in Rasht city during 1990 Manjil earthquake, mainly placed on local lateral unconformities of this unit.

3) Matching the natural period of buildings and ground vibration modes (in alluvium), caused more damage and collapse of mid-rise buildings.

4) Considering the trend of Khazar fault and epicenter location, it is obvious that the Khazar fault contributed to damage in the northern part of Rasht city. 


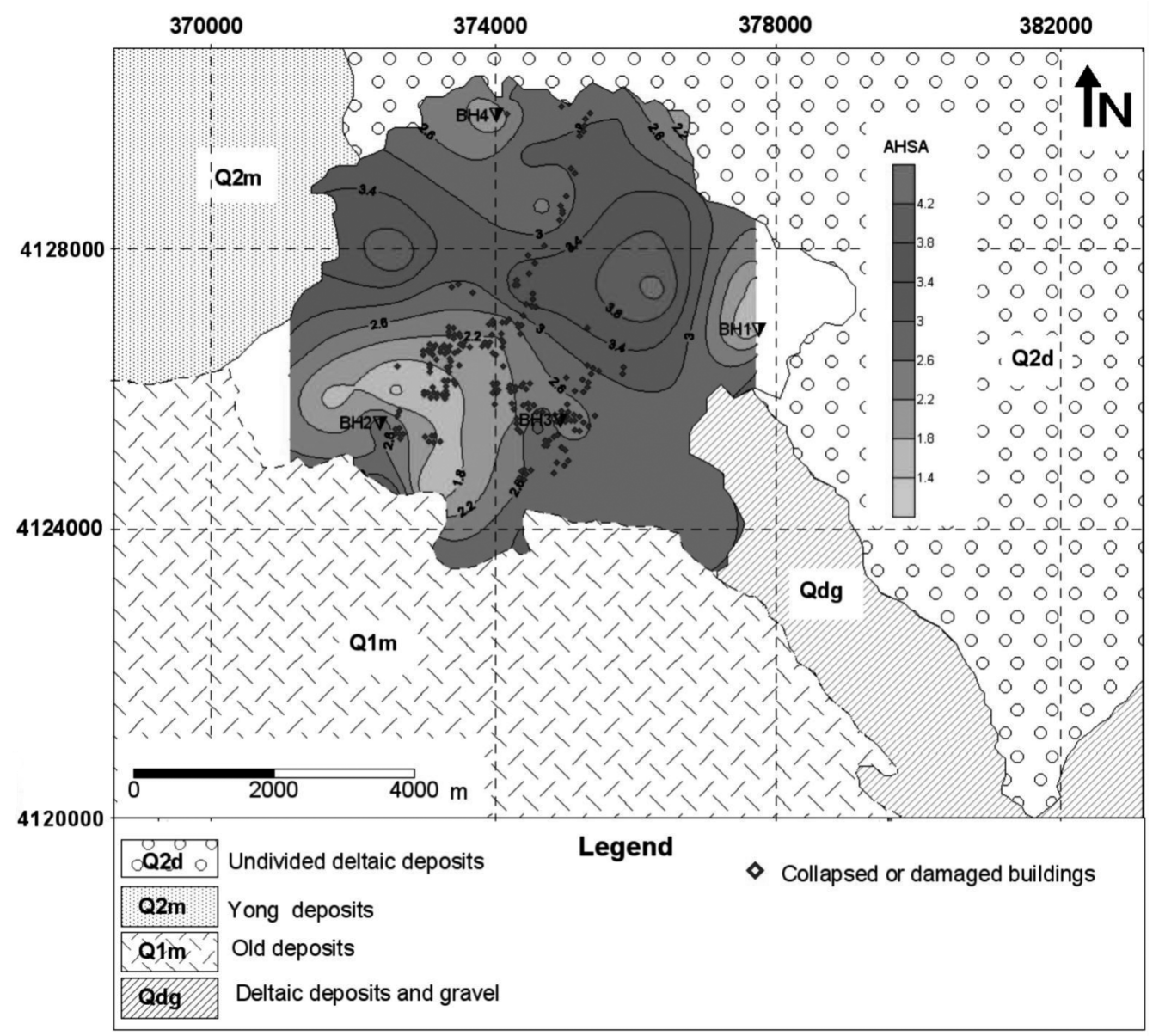

Fig. 12. Variation of average horizontal spectral amplifications (AHSA) throughout Rasht city.

5) AHSA map shows more amplification in east and north compared to center and south of the city, which is supported by geological observations, as in north and east basement is composed of recent sediments, while the south and center mainly consist of old sediments.

6) Sedimentary units in Rasht city are mainly categorized as D class, and part of Q1m sediments falls in C class. Small part of Q2d unit falls in category $\mathrm{E}$ of site classification.

7) The results of this study can be used for land-use planning and strengthening of existing structures against future earthquakes.

\section{Acknowledgments}

The authors thank Dr. Anooshepoor from Nevada seismological laboratory for his critical review and constructive comments. The financial support of the Ministry of Energy and Water Organization of Gilan province is gratefully acknowledged.

\section{REFERENCES}

Berberian, M. and M. Qorashi (1991): The June 20, 1990 Rudbar-Tarom (NW Persian) catastrophic earthquake, 
a preliminary field reconnaissance report. Seismotectonic section, geological survey of Iran, Tehran.

Berberian, M., M. Qorashi, J.A. Jackson, K. Priestley and T. Wallace (1992): The Rudbar- Tarom earthquake of 20 June 1990 in NW Persia: Preliminary field and seismological observations, and its tectonic significance, Bull. Seismol. Am., 82, 1726-1755.

BorChERDT, R.D. (1992): Simplified site classes and empirical amplification factors for site-dependent code provisions, in Proceeding of the "NCEER, SEAOC, $B S S C$ ».

BORCHERDT, R.D. (1994): Estimates of site-dependent response spectra for design (methodology and justification), Earthquake Spectra, 10, 617-653.

Borcherdt, R.D., C.M. Wentworth, A. Janseen, T. FuMAL, and J. GiBBS (1991): Methodology for predictive GIS mapping of special study zones for strong ground shaking in the San Fransisco Bay region, Proc. Fourth International Conf. on Seismic Zonation, Vol. 3, pp. 345-552.

Building And Housing Research CENTER (BHRC) (1999): Iranian code of practice for seismic resistance design of buildings, (Iranian Building Codes and Standards, Standard No. 2800, Tehran, Iran).

Building SeISmic SAFety Council (BSSC) (2001): NEHRP recommended provision for seismic regulations for new buildings and other structure, 2000 edition, part 1 provision, prepared by the Building Seismic Safety Council for the Federal Emergency Management Agency, Report FEMA 368, Washington, DC.

Boore, D. M., W.B. Joyner and T. E. Fumal (1997): Equations for estimating horizontal response spectra and peak acceleration from western North American earthquakes: a summary of recent work, Seismol. Res. Letters, 68, 128-153.

Dobry, R., G.M. Martin, E. Parra and A. BhatTACHARYYA (1992): Development of site-dependent ratios of elastic response spectra (RRS) and site categories for building seismic codes, in Proceeding of the «NCEER, SEAOC, BSSC».

Geological Survey of Iran (2004): 1:100,000 Geological Map of Rasht.

GoRYNOv, N. (1992): Application of seismo acoustic methods in hydrogeology and engineering geology, (Nedra, Moscow).

HAERI, S.M. and M. KHOLAFAIE (1994): Local site effects in city of Rasht during the Manjil earthquake of June 20, 1990, (Iran, Balkema, Rotterdam, Brookfield).

JoYNer, W.B. and D.M. BooRe (1988): Measurements, characterization and prediction of strong ground motion, in Proceedings of the "Earthquake Engineering», vol. 38, (Soil Dynamics II GT Div/ASCE, Park City, Utah, June), pp. 27-30.

MidorikAWA, S (1987): Prediction of isoseismal map in the Kanto plain due to hypothetical earthquake, Journal of Structural Engineering, vol. 33b, pp. 43-48 (in Japanese with English abstract).

Natural Disaster Prevention Center (1994): Microzonation of the city of Rasht, Vol. 1, (in Persian).

NiAZI, M. and Y. BozorgniA (1992): The 1990 Manjil, Iran, earthquake: geology and seismology overview, PGA attenuation, and observed damage, Bull. Seismol. Am., 82, 774-799.

Olsen, K.B. and R.J. Archuleta (1996): Three-dimensional simulation of earthquakes on the Los Angeles fault system, Bull. Seismol. Am., 86, 575-596.

REID, H.F. (1910): The California Earthquake of April 18, 1906: Report of the State Earthquake Investigation Commission, Vol. II, (Carnegie Institution of Washington, Washington, D.C.).

SeEd, R.B., S.E. Dichenson, G.A. Rau, R.K. White and C.M. MoK (1992): Observation regarding seismic response analysis for soft and deep clay sites, in Proceeding of the "NCEER, SEAOC, BSSC».

ShafiEe, A. and A. AzAdi (2007): Shear-wave velocity characteristics of geological units throughout Tehran City, Iran, Journal of Asian Earth Sciences, 29, 105115.

SHERIFF, R.E. and L.P. GELDART (1985): Exploration Seismology, Vol. 1, (Cambridge University Press).

ShimA, E. (1978): Seismic microzoning of Tokyo, (Proc. Second International Conf. on Microzonation), Vol. 1, pp. 433-443.

WALD, L.A. and J. Mori (2000): Evaluation of Methods for Estimating Linear Site-Response Amplifications in the Los Angeles Region, Bull. Seismol. Am., 90, S32-S42.

Wills, C.J., M. Petersen, W.A. Bryant, M. Reichle, G.J. Saucedo, S. Tan, G. TAYlor, and J. Treiman (2000): A site-conditions map for California based on geology and shear-wave velocity, Bull. Seismol. Am., 90, 187208.

Wood, H.O. (1908): Distribution of apparent intensity in San Francisco, in the California earthquake of April, 18, 1906, Report of the state earthquake investigation commission, (Carnegie institute of Washington, Washington, D.C.), Vol. 1, pp. 220-245.

ZENG, Y. (1993): Theory of scattered P and S waves energy in a random isotropic scattering medium, Bull. Seismol. Am., 83, 1264-1276.

(received September 29, 2008; accepted March 23, 2009) 